
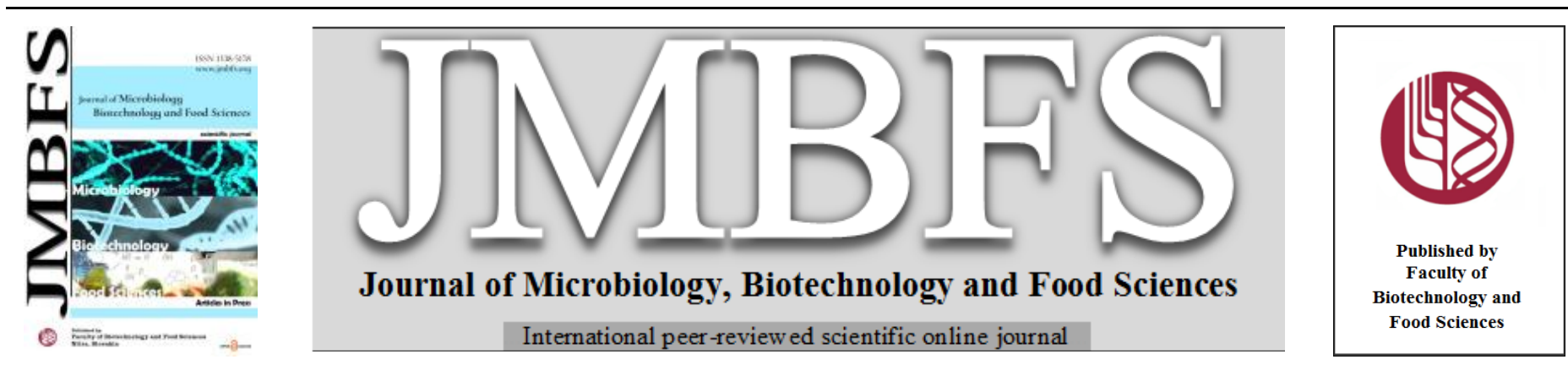

\title{
ISOLATION, CHARACTERIZATION AND IDENTIFICATION OF MULTIFACETED HALOTOLERANT BACILLUS LICHENIFORMIS AND BACILLUS WUDALIANCHIENSIS FROM RHIZOSPHERIC SOILS OF BANGALORE
}

\author{
Rekha Vekataramappa ${ }^{1,2}$., Nithin Kumar Mahadev ${ }^{l, 2}$., Sadhana Venkatesh ${ }^{l}$., Kavitha Balakrishnan ${ }^{2}$, Sandeep Suryan ${ }^{l}$, Nagananda \\ Govinahalli Shivashankar ${ }^{l}$, Swetha Seshagiri ${ }^{1 *}$
}

Address(es):

${ }^{1}$ Centre for Incubation, Innovation, Research \& Consultancy (CIIRC), Plant and microbial technology laboratory, Jyothy Institute of Technology, Tataguni, off Kanakapura road, 560082, Bengaluru, Karnataka, Phone number: +91 9741887660.

${ }^{2}$ Government Science College (Autonomous), Nrupathunga Road, Bangalore- 500 001, Bengaluru, Karnataka.

*Corresponding author: swetha.s@ ciirc.jyothyit.ac.in

https://doi.org/10.55251/jmbfs. 3553

\section{ARTICLE INFO}

Received 7. 8. 2020

Revised 29. 1. 2022

Accepted 31. 1.2022

Published 1. 6. 2022

Regular article OPEN ${ }_{\text {ACCESS }}$

\begin{abstract}
Plant growth promotion through versatile microorganisms inhabiting the rhizospheric region of the soil has emerged as a sustainable approach in improving the crop productivity and crop health management. The present study reports the isolation and characterization of halotolerant as well as drought tolerant isolates that possess exceptional plant growth promotional attributes. Out of 32 isolates obtained, 13 isolates exhibited excellent plant growth promotional attributes such as phosphate solubilization, phytohormone production, siderophore production etc. Among 13 isolates tested for stress tolerance studies, two isolates Mulberry -1 and Ragi-7 were able to tolerate both drought and saline stresses and were further identified as Bacillus licheniformis and Bacillus wudalianchiensis based on biochemical and molecular techniques. Antibiosis activity of both the isolates tested against two important plant pathogens Fusarium oxysporum and Phomopsis vexans was found to be positive. Bacillus licheniformis and Bacillus wudalianchiensis were further tested for their efficacy to solubilize five different inorganic phosphate sources. The amount of phosphate liberated was found to be highest $\left(3562 \mathrm{mgml}^{-1}\right.$ and 1894 $\mathrm{mgml}^{-1}$ ) with diammonium phosphate followed by single super phosphate and tricalcium phosphate with respect to Bacillus licheniformis and Bacillus wudalianchiensis. Zea mays L. seeds treated with the culture filtrate of both the isolates were cultivated on Murashige-Skoog medium under In-vitro conditions. Bacillus wudalianchiensis was found to be better compared to Bacillus licheniformis with respect to plant growth promotional aspects as they were able to increase the root and shoot length of Zea mays L. under In-vitro conditions. Application of the multifaceted capabilities of unexplored halotolerant strain of Bacillus wudalianchiensis could open up a new avenue in plant biotechnology.
\end{abstract}

Keywords: Bacillus wudalianchiensis; Bacillus licheniformis; Halotolerant; Phosphate Solubilization Studies; In-vitro plant studies

\section{INTRODUCTION}

Rhizosphere is a dynamic environment surrounding plant roots which harbours diverse group of microbes. Some of the bacteria from this zone are termed as "rhizobacteria", which effectively colonize the plant roots. Release of organic compounds from the plant roots serve as nutrients to the microbial community present in the rhizospheric soil. The microorganism inhabiting the rhizosphere, engineers the rooting pattern, activates the plant defense mechanism and improves nutrient uptake in plants (Cruz et al., 2002; Barea et al., 2005). Plant growth promoting rhizobacteria (PGPR) play a cardinal role in reducing the application of chemical fertilizers to a larger extent by extensively promoting the exchange of plant nutrients. Several mechanisms are being reported in the literature by which rhizospheric microorganisms stimulate the plant growth (Kiely et al. 2006).

Microorganisms play an imperative role in agriculture as they are very much essential for the decomposition of organic matter and recycling of old plant material. Some soil bacteria and fungi form symbiotic association with various plant roots there by helping in facilitating certain essential nutrients like nitrogen or phosphorous to plants.

Although soil microorganisms comprise $<1 \%$ of the total mass of a soil, they play a vital role in supporting all living beings. Some of the functions of rhizobacteria are: (i) Break down of organic matter (ii) Nitrogen fixation (iii) Creation of soil structure (iv) Creation of humus (v) Recycling of soil nutrients (vi) Phosphate solubilization and (vii) Plant growth promotion.

Among several PGPR, Bacillus spp. have gained considerable attention and are most widely used as bacterial inoculants. Bacillus species possess wide metabolic capabilities allowing them to exhibit significant characteristics in soil ecosystem functions and processes. Due to their heterotrophic nature, Bacillus spp. are also important in fixing carbon $(\mathrm{C})$, nitrogen and sulfur $(\mathrm{S})$ in the soil along with transformation of certain other soil nutrients (Mandic- Mulec and Prosser 2011). Several studies have reported the beneficial role of various Bacillus species in plant growth promotion, increased yield, phytohormone production, phosphorus (P) solubilization and nutrient uptake (Cakmakci et al.2006, Khan 2010).

Maize is considered as the third most significant cereal crop and it has become staple nourishment in numerous parts of the world. It is mainly utilized as a food for human, feed for livestock and as a raw material for various industries (Khatoon et al., 2010). It is cultivated widely in various soil and climatic conditions. It plays a magnificent role in the country's economy by feeding malnourished people as well as in solving country's food problems. Maize encompasses more digestible protein than any other cereals (Hassan et al., 2018).

The present study focuses on isolation of an exceptional, halotolerant and drought tolerant rhizobacteria possessing plant growth promotional attributes from the rhizospheric soils of rural Bangalore.

\section{MATERIAL AND METHODS}

\section{Soil sampling and isolation of plant growth promoting rhizobacteria}

Soil samples from the rhizospheric region of various crops such as ragi, mulberry, corn, sugar cane and paddy were collected from the agricultural fields of rural Bangalore in the month of February 2019. Geographically the study area/ collection site falls in the longitude of $77023^{\circ} 45^{\prime \prime} \mathrm{E}$ and $77038^{\circ} 20^{\prime \prime} \mathrm{E}$ and latitude of $12038^{\circ} 55^{\prime \prime} \mathrm{N}$ and $12052^{\prime} 20^{\prime \prime} \mathrm{N}$. A total of 10 samples were collected carefully in a sterilized container and sieved to remove any debris prior to isolation. 10 grams of soil sample from each crop was serially diluted and plated onto nutrient agar medium using standard microbiological techniques. Plates were incubated at $30^{\circ} \mathrm{C}$ for 48 hours. 


\section{In-vitro assessment of plant growth promoting attributes}

Plant growth promotional attributes of bacterial isolates were assessed for inorganic phosphate solubilization, indole-3-acetic acid (IAA) production, siderophore, $\mathrm{HCN}$, ammonia production and antifungal activity against two potent plant pathogens. All assays were carried out in triplicates.

\section{Phosphate solubilization}

Solubilization of inorganic phosphate by the isolates was detected by cultivating them on National Botanical Research Institute Phosphate- Bromophenol blue (NBRIP-BPB) medium containing tricalcium phosphate as a inorganic phosphate source. $\mathrm{pH}$ of solubilization medium was adjusted to $5.8 \pm 0.2$ and incubated at $37 \pm 2^{\circ} \mathrm{C}$ for 5 days. Formation of clear zone around the colonies was taken as positive. Uninoculated NBRIP-BPB media served as a control (Nautiyal 1999).

\section{Indole acetic acid production}

IAA production by selected bacterial isolates was investigated by cultivating them in nutrient broth supplemented with $0.1 \%$ Tryptophan and incubated at $37^{\circ} \mathrm{C}$ for $48 \mathrm{~h}$ under continuous shaking conditions (100 rpm). Further, the culture broth was centrifuged at $5000 \mathrm{rpm}$ for 10 minutes. $1 \mathrm{ml}$ of the supernatant was mixed with $2 \mathrm{~m}$ of Salkowski's reagent (colour reagent) and kept at room temperature for 20 minutes. For negative control, un-inoculated nutrient broth containing $0.1 \%$ tryptophan was mixed with the Salkowski's reagent. Development of pink colour upon addition of colour reagent indicated the production of IAA. Quantity of IAA produced was calculated against a standard curve prepared with different concentrations of standard IAA (Padmavathi et al., 2016a).

\section{Siderophore production}

Siderophore production capability of the isolates was evaluated by inoculating the test organisms on chrome azurol S (CAS) agar and incubated at $37^{\circ} \mathrm{C}$ for $4-5$ days Appearance of orangish brown coloured colony was considered as positive for siderophore production. The isolates that produced orange coloured colonies with clear zones around them were scored as siderophore producers (Schwyn and Neiland 1987).

\section{Hydrogen cyanide production}

A loop full of bacterial isolates was inoculated into sterile nutrient broth amended with $4 \%$ Glycine. Whatmann No. 1 filter paper strips soaked in $0.5 \%$ picric acid and $2 \% \mathrm{Na}_{2} \mathrm{CO}_{3}$ solution were placed towards the end of the test tube and the tubes were incubated for $48 \mathrm{~h}$ at $37^{\circ} \mathrm{C}$. Change in the colour of the filter paper from yellow to orange brown colour was considered as positive for the $\mathrm{HCN}$ production (Baker and Schippers, 1987)

\section{Ammonia production}

For ammonia production, isolates were inoculated into $5 \mathrm{ml}$ of sterile peptone wate and incubated at $37^{\circ} \mathrm{C}$ for $48 \mathrm{~h}$. After the bacterial growth, $0.5 \mathrm{ml}$ of Nessler's reagent was added to the broth. Development of yellow to brown colour was observed and indicated as positive for ammonia production (Cappuccino and Sherman, 1992). Uninoculated medium served as control.

\section{Stress tolerance studies}

\section{Drought tolerance}

In order to study the ability of the isolate to endure drought stress, isolates were cultivated on nutrient agar supplemented with different concentrations of polyethylene glycol (PEG) ranging from $0 \%$ to $16 \%$ at $37^{\circ} \mathrm{C}$ for 48 hours (Swetha and Padmavathi, 2019).

\section{Halotolerance assay}

Bacterial isolates were screened for halotolerance by cultivating them on nutrient agar medium supplemented with various concentrations of sodium chloride $(0 \mathrm{mM}$ to $240 \mathrm{mM}$ ). The plates were incubated at $30 \pm 2^{\circ} \mathrm{C}$ for $48 \mathrm{~h}$ (Albdaiwi et al., 2019)

\section{Biochemical profiling}

The potential isolates that exhibited tolerance to drought and salt stress were further characterized using biochemical and molecular techniques (16srRNA sequencing). Potential isolates were screened for indole, methyl red, VogesProskauer test as per standard protocols (Harley and Prescott, 2002). For citrate utilization test, bacterial isolates were cultivated on Simmons citrate medium and incubated at $30 \pm 2{ }^{\circ} \mathrm{C}$ for 48 hours; change in the colour of the medium from green to blue was taken as positive. For catalase test, potential isolates were smeared on clean glass slide and few drops of $3 \%$ hydrogen peroxide were added on to the smear. Appearance of bubbles confirmed the presence of catalase activity. For oxidase test, a loop full of test organism was streaked in a zigzag manner on the oxidase disk. Development of dark purple colour on the disk after 10-15 second indicated positive for oxidase. Carbohydrate utilization efficacy of isolates against various carbohydrates such as glucose, sucrose, mannitol and lactose was studied by inoculating potential isolates in triple sugar medium. The test cultures were stab inoculated onto hydrogen sulphide media and incubated at $37 \pm 2{ }^{\circ} \mathrm{C}$ for $24-48 \mathrm{~h}$ The formation of black precipitate in the medium indicated positive for the test.

\section{Molecular identification and phylogenetic tree analysis}

The genomic DNA was isolated according to Sambrook and Russel (2001) Amplification of 16S rRNA gene of two potential isolates M-1 and R-7 was carried out using universal eubacterial primers FD1 5_ CCG AAT TCG TCG ACA ACA GAG TTT GAT CCT GGC TC AG 3_ and RD1 5_ CCC GGG ATC CAA GCT TAA GGA GGT GAT CCAGCC 3_(Weisburg et al., 1991). Similarity of 16S rRNA gene sequence was aligned using BLAST programme of GenBank database (NCBI).

\section{Extracellular enzymes production by two potential isolates M1 and R7}

\section{Chitinase production}

Potential isolates M1 and R7 were inoculated on to nutrient agar plate supplemented with colloidal chitin and incubated at $37^{\circ} \mathrm{C}$ for $24 \mathrm{~h}$. After incubation, the plates were stained with $0.1 \%$ congo red and distained with $1 \%$ sodium chloride, clear zone around the colony indicated positive results.

\section{Pectinase production}

Pectinase production was investigated by inoculating M1 and R7 on to Vincent's agar plate for 24 hours at $37^{\circ} \mathrm{C}$. Formation of clear zone around the colonies upon addition of iodine solution was considered as positive for pectinase production (Venkata et al., 2013).

\section{Starch hydrolysis /amylase production}

Bacterial isolates M1 and R7 were streaked on to starch agar plates and incubated for $24 \mathrm{~h}$ at $37^{\circ} \mathrm{C}$. Further the plates were flooded with iodine solution. Appearance of clear zone around the colonies was considered as positive.

Casein/protease: M1 and R7 were subjected to screening for protease enzyme production by inoculating them on to skimmed milk agar medium and incubated at $37^{\circ} \mathrm{C}$ for $24 \mathrm{~h}$. Appearance of clear zone around the colonies was taken as positive.

\section{Antibiosis/ antifungal activity}

An $8 \mathrm{~mm}$ diameter agar plugs containing Fusarium oxysporum and Phomopsis vexans mycelium were placed in the centre of the plate containing potato dextrose agar medium and incubated at $25^{\circ} \mathrm{C}$ for $48 \mathrm{~h}$. Isolates $\mathrm{M} 1$ and $\mathrm{R} 7$ were cultured in nutrient broth and were centrifuged at $5000 \mathrm{rpm}$ for 20 minutes. Two wells of 6 $\mathrm{mm}$ diameter on either side of the fungal culture were bored in the inoculated media with the help of a sterile cork-borer. $100 \mu \mathrm{l}$ of the cell free supernatant was filled in each well. Further, the plates were incubated at $37^{\circ} \mathrm{C}$ for $18-24$ hours. Formation of inhibition zone around the fungal colony was observed which in turn corresponds to the antifungal activity of the cell free supernatant (Kandel $\boldsymbol{e t} \boldsymbol{a l}$., 2017).

\section{Phosphate Solubilization Studies by M1 and R7}

Different phosphate sources such as Tricalcium phosphate (TCP), Di-ammonium phosphate (DAP), Aluminum phosphate (AlP), Zinc phosphate (ZnP) and Single super phosphate (SSP) were used in the present study.

\section{Phosphate solubilization by M1 and R7 in Liquid medium}

Phosphate solubilization in liquid medium was performed by inoculating M1 and R7 isolates in Pikovskaya's broth amended with five different phosphate sources tricalcium phosphate (TCP), diammonium phosphate (DAP), aluminium phosphate (AlP), zinc phosphate (ZnP) and single super phosphate (SSP). The initial $\mathrm{pH}$ of the medium was adjusted to 7 . After sterilization of the media, M1 and $\mathrm{R} 7$ were inoculated and incubated at $37^{\circ} \mathrm{C}$ for 2 days under continuous shaking conditions. Amount of phosphate liberated, titratable acidity, production of organic acid and drop in $\mathrm{pH}$ were analyzed (Swetha and Padmavathi 2016).

\section{Phosphate estimation}

Amount of phosphate liberated upon solubilization of different inorganic phosphate sources by M1 and R7 isolates was assessed according to method as described by Fiske-Subbarow (Fiske and Subbarow, 1925). 


\section{Titratable acidity}

In order to determine the titratable acidity, a known amount of culture filtrate was titrated with $0.1 \mathrm{M} \mathrm{NaOH}$ in the presence of phenolphthalein as an indicator. Drop in $\mathrm{pH}$ of the media was also recorded using digital $\mathrm{pH}$ meter (Swetha and Padmavathi 2016)

\section{Plant- microbe interaction studies}

Zea mays L. seeds obtained from local farmers were sterilized with $70 \%$ ethanol for 30 seconds and $2 \%$ sodium hypochlorite for $1 \mathrm{~min}$, followed by rinsing for several times with sterile deionized water. The bacterial cultures were grown in nutrient broth at $30^{\circ} \mathrm{C}$ for $24 \mathrm{~h}$ with $150 \mathrm{rpm}$. Bacterial cells were harvested by Fully grown culture was subjected to centrifugation at $5000 \mathrm{rpm}$ for $5 \mathrm{~min}$ at $4^{\circ} \mathrm{C}$ in order to harvest bacterial cells. Cell pellets were resuspended in saline to achieve a cell density of $1.0 \times 10^{8} \mathrm{CFU} \mathrm{mL}^{-1}$. Seed bacterization process was performed by soaking the Zea mays L. seeds in bacterial suspensions along with $1 \%$ Carboxy Methyl Cellulose (CMC) for 4 hours whereas the control seeds were soaked only in sterile water. After 4 hours of seed treatment, the seeds were air dried and transferred to culture bottles containing Murashige and Skoog medium (Kiely $\boldsymbol{e} t$ al., 2006). Treatments used in the present study are (i) Control (ii) Treated with M1 isolate (iii) Treated with R7 isolate (iv) Treated with Co-culture (M1 and R7). Culture bottles were placed in a growth chamber at $22{ }^{\circ} \mathrm{C}$ with a photoperiod of $16 / 8 \mathrm{~h}$ (light/dark). Ten days after inoculation, the seed germination and phenotypic characterization was determined.

\section{RESULTS AND DISCUSSION}

\section{Isolation of Rhizospheric Microorganisms}

A total of 32 bacterial colonies were isolated from the rhizospheric region of various crops such as ragi, mulberry, corn, sugar cane and paddy. Out of these 32 isolates, 10 were Gram positive rods, 17 were Gram negative rods and six were found to be Gram positive cocci based on the colony morphology and Gram staining technique.

\section{Plant growth promotional attributes}

All the 32 isolates were subjected to check their ability to exhibit plant growth promotional attributes, of these 13 isolates showed positive for all the tested plant growth promotional attributes such as phosphate solubilization, production of phytohormone, siderophore production, $\mathrm{HCN}$ and ammonia production (Table 1). Phosphorus is one of the essential macronutrient which plays a prominent role in the development of plant roots, flowers, helps in crop maturity, seed formation and offers resistance to plant diseases (Swetha and Padmavathi, 2016). Production of phytohormones such as auxins (IAA) and gibberellins is one of the mechanisms among several other mechanisms by which rhizospheric microorganisms stimulate the plant growth. IAA molecules serve as signalling molecules which are necessary for the development of plant organs (Swetha and Padmavathi, 2016b).

Out of 13 isolates, six isolates exhibited excellent siderophore production on CAS media. Two isolates did not exhibited siderophore production on CAS media Siderophore production by rhizobacteria plays a vital role in stimulating plant growth and also in controlling several plant diseases. They are also responsible for inducing systemic resistance (ISR) in plants. Siderophores are directly involved in stimulating the production of certain antimicrobial compounds via increasing the availability of essential trace minerals to the bacteria (Solanki MK et al., 2013) Almost all the bacterial isolates showed positive result for ammonia production whereas only eight isolates were effective in producing $\mathrm{HCN}$. $\mathrm{HCN}$ production by rhizobacteria is one of the important attribute which plays an important role in the biological control of several soil-borne pathogenic fungi (Ramette et al., 2003) Ammonia producing bacteria are involved in converting Nitrogen $\left(\mathrm{N}_{2}\right)$ to Ammonia $\left(\mathrm{NH}_{3}\right.$ ), making it an available nutrient for the plants (Hayat et al. 2010). Hence application of ammonia producing bacteria may effectively enhance/boost the plant growth.

Table 1 Screening of PGPR Traits

\begin{tabular}{|c|c|c|c|c|c|c|}
\hline S1. No. & Isolates & Phosphate & Siderophore & Ammonia & $\mathrm{HCN}$ & IAA \\
\hline 1 & Ragi $10^{-2}-7$ & +++ & ++ & ++++ & - & ++ \\
\hline 2 & Ragi $10^{-2}-2$ & +++ & ++++ & ++++ & - & ++ \\
\hline 3 & Ragi $10^{-2}-3$ & +++ & +++ & ++ & - & - \\
\hline 4 & Ragi $10^{-2}-4$ & +++ & - & +++ & + & - \\
\hline 5 & Ragi $10^{-4}-1$ & +++ & +++ & +++ & + & ++++ \\
\hline 6 & Mulberry $10^{-2}-3$ & +++ & + & +++1 & + & +++ \\
\hline 7 & Mulberry $10^{-4}-2$ & +++ & + & ++++ & + & - \\
\hline 8 & Mulberry $10^{-4}-1$ & +++ & +++ & ++++ & + & - \\
\hline 9 & Corn $10^{-2}-1$ & +++ & ++++ & ++ & - & - \\
\hline 10 & Corn $10^{-2}-2$ & +++ & ++ & ++ & + & ++ \\
\hline 11 & Corn $10^{-4}-1$ & +++ & - & ++ & - & ++ \\
\hline 12 & Paddy $10^{-2}-7$ & ++++ & ++ & +++ & + & - \\
\hline 13 & Sugar cane $10^{-2}-1$ & +++ & +++ & +++ & + & ++ \\
\hline
\end{tabular}

Table 2 Biochemical characteristics of selected bacterial isolates

\begin{tabular}{lccc}
\hline Sl. No. & Biochemical Tests & Mulberry 1 & Ragi 7 \\
\hline 1 & Catalase test & + & + \\
\hline 2 & Oxidase Test & + & - \\
\hline 3 & Indole Test & + & + \\
\hline 4 & Methyl Red Test & + & - \\
\hline 5 & Voges-Proskauer Test & + & - \\
\hline 6 & Gelatin Hydrolysis & + & - \\
\hline 7 & Citrate Utilization Test & + & + \\
\hline 8 & Hydrogen Sulfide Test & + & - \\
\hline & Carbohydrate Test & & \\
\cline { 2 - 4 } & Glucose & + & - \\
\cline { 2 - 4 } & Sucrose & + & - \\
\cline { 2 - 4 } & Mannitol & + & - \\
\hline
\end{tabular}

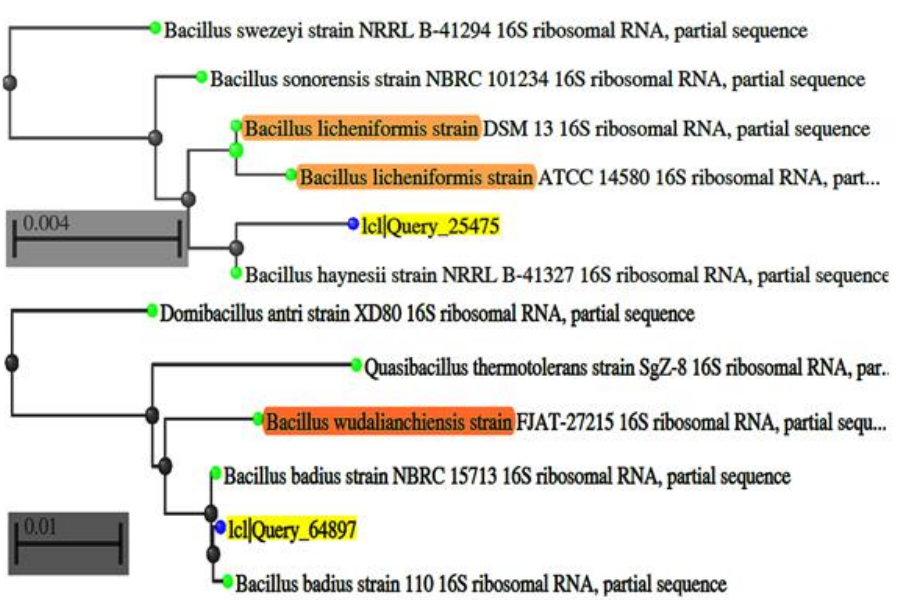

Figure 1 Phylogenetic tree of potential isolates was constructed using phylogeny.fr

\section{Extracellular enzymes production by two potential isolates M1 and R7}

Figure 2 illustrates the extracellular enzyme production by BacIillus licheniformis and Bacillus wudalianchiensis. Both the isolates showed positive for chitinase, pectinase, starch hydrolysis and casein hydrolysis. A hydrolytic enzyme like 
protease, amylase, chitinase and cellulase are capable of degrading the fungal cellwall. Most of the plant growth promoting rhizobacteria is capable of producing these extracellular enzymes that can hydrolyze the variety of complex polymeric compounds like cellulose, hemicellulose, chitin, proteins and pectin present in the cell wall of pathogenic fungi. These extracellular hydrolytic enzymes alter the structural integrity of the cell wall of the targeted pathogens (Budi et al., 2000) Chitinase enzymes are responsible for the degradation of chitin present in the cell wall of fungal phytopathogenes (Kim et al., 2003). These enzymes can either be used directly/ indirectly in the biocontrol activity of fungal pathogens. Proteases are a large group of enzymes that play a significant role in the lysis of cell wall of phytopathogenic fungi, as the major constituents of the fungal cell wall are embedded into the protein matrix. Protease enzyme helps in breaking down of major proteins of phytopathogens into peptide chains and/or their constituent amino acids (Jadhav and Sayyed, 2016). The biocontrol capability of plant growth promoting rhizobacteria is dependent on the production of the above mentioned hydrolytic enzymes (Kobayashi et al., 2002).
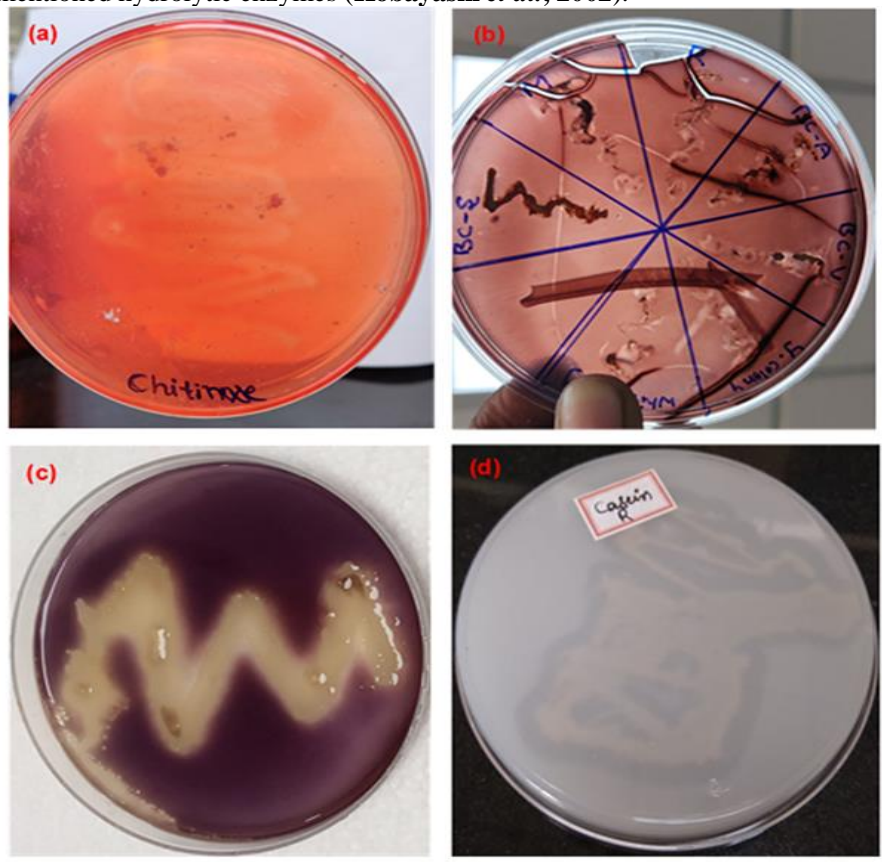

Figure 2 Screening of extracellular enzymes. A- Chitinase, B-Pectinase, CStarch, D-Casein

\section{Antibiosis/ Antifungal activity}

Fusarium oxysporum and Phomopsis vexans are two important plant pathogens which are responsible for the destruction of various crops. Bacillus licheniformis and Bacillus wudalianchiensis exhibited excellent antifungal activity against both the fungal pathogens (Figure 3).

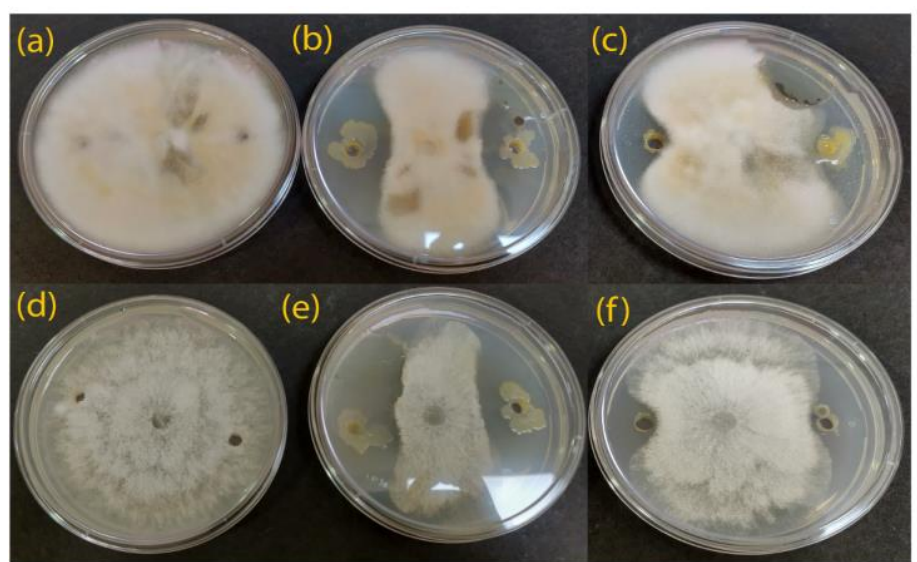

Figure 3 Production of diffusible antifungal metabolites by Bacillus licheniformis and Bacillus wudalianchiensis active against Fusarium oxysporum and Phomopsis vexans(a) Fusarium oxysporum Control (b) Fusarium oxysporum and Bacillus licheniformis (c) Fusarium oxysporum and Bacillus wudalianchiensis (d) Phomopsis vexans Control (e) Phomopsis vexans and Bacillus licheniformis (f) Phomopsis vexans and Bacillus wudalianchiensis .

\section{Phosphate Solubilization Studies by M1 and R7}

Figure 4 represents the amount of phosphate liberated by both the isolates Bacillus licheniformis and Bacillus wudalianchiensis for all the five substrates. The amount of phosphate liberated was found to be highest with DAP followed by SSP and TCP. Both the organisms were not able to solubilize $\mathrm{ZnP}$ and AlP. Bacillus licheniformis was found to be better in solubilizing all the five substrates compared to Bacillus wudalianchiensis. The obtained results are in conformity with the results of Selvi et al., (2011) who have also reported the highest phosphate solubilization in potassium di hydrogen phosphate followed by tricalcium phosphate, aluminum phosphate and iron phosphate by isolated Bacillus $s p$.

Although the solubilization of different inorganic forms of phosphate by Bacillus licheniformis was found to be better compared to Bacillus wudalianchiensis; a detailed study on phosphate solubilization involving titratable acidity, drop in $\mathrm{pH}$ and organic acid production was performed with Bacillus wudalianchiensis as the isolate is not much explored in terms of plant growth promotional attributes.

Percentage of titratable acidity was found to be the highest $(0.47 \%)$ with DAP (Figure 5). Titratable acidity of 0.11 and $0.18 \%$ for SSP and TCP was obtained respectively. These results clearly explain that phosphate solubilization occurs via carboxylic acids released by microorganisms, resulting in decrease in the $\mathrm{pH}$ of the media. An increase in titratable acidity with decrease in $\mathrm{pH}$ was recorded with all the phosphate sources which concur with the results obtained by Swetha and Padmavathi (2016b). Similar studies on solubilization of TCP, RP and AlP by various microorganisms have been reported earlier. Likewise, Panhwar $\boldsymbol{e t}$ al. (2011) have studied the solubilization of triple super phosphate by two species of Bacillus namely PSB 9 and PSB 16. Change in the $\mathrm{pH}$ of the medium is completely dependent on the type of phosphate source present in the medium and the mechanism includes modification of $\mathrm{pH}$ by the secretion of organic acids and protons or cation dissociation (Selvi et al., 2011)

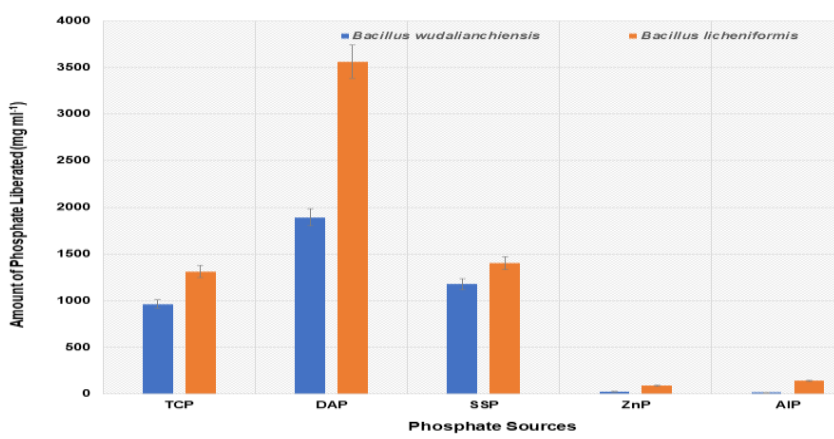

Figure 4 Plots depicting Solubilization of Five different Phosphate sources by Bacillus licheniformis and Bacillus wudalianchiensis

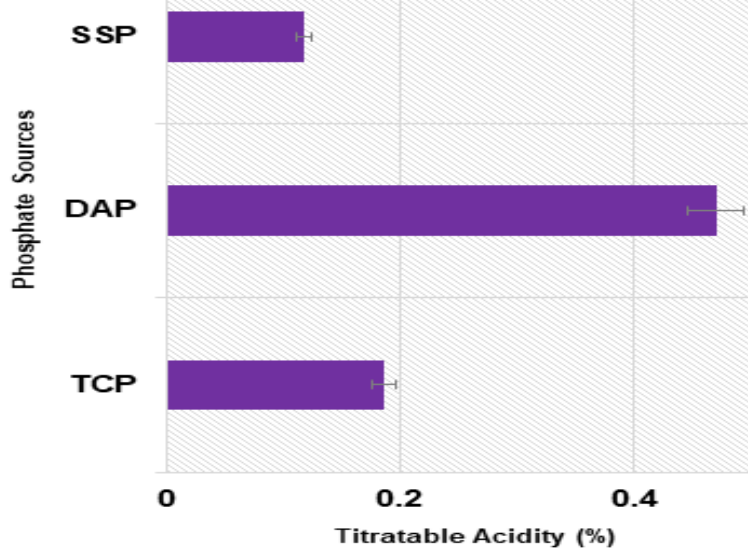

Figure 5 Plots depicting Titratable Acidity

\section{Plant- Microbe Interaction Studies}

Seeds of Zea mays L. were treated with cell suspensions of two different rhizobacteria Bacillus licheniformis (M1) and Bacillus wudalianchiensis (R7) under in vitro conditions (Omar et al.,2014). Figure 6 illustrates the effect of bacterial isolates on the germination of Zea mays L seeds under In-vitro conditions. The results revealed that treatment with both the bacterial isolates induced the plant growth promotion significantly over untreated plants. Among the two rhizobacteria used in the study, R7 isolate (Bacillus wudalianchiensis) was found to be better than the M1 (Bacillus licheniformis) in enhancing the plant growth with respect to increase in root length and shoot length. 
The results revealed that dual inoculation of both Bacillus wudalianchiensis and Bacillus licheniformis increased the growth of Zea mays L seedlings significantly when compared to untreated control.

Several reports have indicated that bacterization of seeds with Pseudomonas and Bacillus spp. was found to promote the plant growth. Nagendran (2011) reported that bacterization of seed with bacterial endophytic Bacillus strains viz., EPB 18 , EPB 11, EPCO 74, EPB 6 and FZB24 were found to enhance the vigour index of the rice seedlings under In-vitro conditions.

Similarly, co-culture studies involving strains of Bacillus possessing multiple plant growth promotional attributes were found to be more effective in enhancing the growth of wheat plants (Baig et al., 2012).

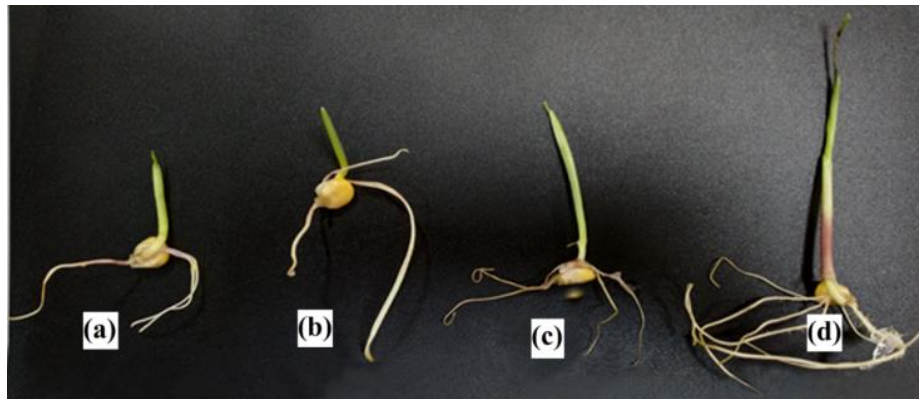

Figure 6 Effect of bacterial isolates on the germination of Zea mays L seeds unde In-vitro conditions. (a)Control (b) Bacillus licheniformis (c) Bacillus wudalianchiensis $\quad$ (d) Bacillus licheniformis and Bacillus wudalianchiensis

Plant growth promoting rhizobacteria play an exceptional role in agriculture by promoting the exchange of plant nutrients and reducing the application of chemical fertilizers to a larger extent.

There are several mechanisms by which rhizospheric microorganisms stimulate the plant growth (Kiely et al. 2006). The direct mechanisms involved in PGPR mediated plant growth promotion are phosphorus solubilization, HCN production, nitrogen fixation, production of phytohormones such as auxins, cytokinins and gibberellins and lowering of ethylene concentration. Among all the other mechanisms; phosphate solubilisation is one of the most important plant growth promoting traits. Availability of phosphorous is also responsible for the functioning of certain key enzymes which are involved in the regulation of many metabolic pathways (Swetha and Padmavathi 2016). One of them includes the production of IAA which plays a prime role in the plant's life cycle by controlling many physiological processes such as cell enlargement and cell division, tissue differentiation, responses to light and gravity etc which are essential for the development of plant. According to the several reports available in literature, application of certain strains of PGPR to various crop plants at an initial stage of development improves the biomass production through direct effects on root and shoots growth. Some of the examples of PGPRs which have been widely exploited for plant growth promotion and suppression of crop diseases are fluorescent Pseudomonads, Bacillus spp., Azotobacter spp., Azospirillum spp etc. Among the PGPR, Bacillus spp are the most widely exploited bacterial inoculants, which possess wide metabolic capabilities allowing them to exhibit significant characteristics in soil ecosystem functions and processes.

Three endophytic bacterial isolates of Bacillus namely BECS3, BECS6 and BECS7 were proven to be very efficient as they exhibited both antagonistic as well as plant growth promoting activities in tomato and chilli plants upon seed bacterization (Amaresan et al., 2012). In a similar study, bacterial strains viz., EPC 5, EPC 8, EPC 15, EPC 29 and EPC 52 were found to increase the vigour index of rice seedlings significantly (Rajendran 2007).

Bacillus wudalianchiensis, a gram positive endospore forming aerobic rods are motile by means of lateral flagella and are rod-shaped bacterium with rounded ends. They possess ellipsoidal endospores which lie at a central position in slightly swollen sporangia. Bacillus wudalianchesis possess a pronounced growthpromoting activity and also found to increase the resistance to plants under various environmental stresses including salinity, drought and plant pathogens (Liu et al., 2017). However, Bacillus wudalianchiensis is a novel and unexplored species of Bacillus, thus an in-depth study on this particular halotolerant versatile species of Bacillus can be very helpful in plant biotechnology field for amelioration of abiotic and biotic stresses in various plants. Bacillus licheniformis is a gram positive mesophilic bacteria commonly found in the soil. Bacillus licheniformis are beneficial bacteria which have the ability to colonize the roots and promote plant growth through either direct or indirect mechanism or via biological control of plant diseases. They are associated with many plant species and are generally present in varied environments (Hurek and Reinhold-Hurek, 2003).

In a nutshell, the present study has demonstrated the possibility of application of multifaceted Bacillus licheniformis and Bacillus wudalianchiensis as a biofertilizer in increasing the plant growth in Zea mays L. under In-vitro conditions. Bacillus licheniformis and Bacillus wudalianchiensis have well demonstrated the fungistatic/ fungitoxic nature alongside various plant growth promoting attributes. Both the strains have incredible/tremendous potential for inoculum production and exhibit a lot of competitive advantages in colonization of rhizosphere.

\section{CONCLUSION}

In the present study, 32 isolates were obtained from the rhizospheric soils of various crops. Out of 32 isolates, 13 exhibited excellent plant growth promotional attributes such as phosphate solubilization, phytohormone production, siderophore production, $\mathrm{HCN}$ and ammonia production. Among 13 isolates tested for stress tolerance studies, two isolates Mulberry -1 (M1) and Ragi-7 (R7) were able to endure both the stresses. M1 and R7 were identified as Bacillus licheniformis and Bacillus wudalianchiensis respectively based on 16s rRNA gene sequence analysis. Both the isolates exhibited antibiosis against most potent phytopathogens; Fusarium oxysporum and Phomopsis vexans. Production of extracellular hydrolytic enzymes such as chitinase, protease, pectinase and starch hydrolysis were observed with both the isolates. Bacillus licheniformis and Bacillus wudalianchiensis were tested for their efficacy to solubilize five different inorganic phosphate sources such as tricalcium phosphate, diammonium phosphate, aluminium phosphate, zinc phosphate and single super phosphate. The amount of phosphate liberated was highest with diammonium phosphate followed by single super phosphate and tricalcium phosphate. Both the isolates were not able to solubilize zinc phosphate and aluminium phosphate. Among the two rhizobacteria used in the study, Bacillus wudalianchiensis was found to be better compared to Bacillus licheniformis with respect to plant growth promotional aspects as they were able to increase the root and shoot length of Zea mays L. under In-vitro conditions. Dual inoculation studies of both the strains were found to be more effective than single strain.

Deeper understanding of the multifaceted capabilities of unexplored halotoleran strain of Bacillus wudalianchiensis could open up a new avenue/ horizon in plan biotechnology. Dual inoculation of the versatile species of Bacillus (Bacillus wudalianchiensis and Bacillus licheniformis) can be a promising approach in the improvement of plant growth and suppression of various diseases in several plants thereby helping the farmers to increase crop productivity in a better way.

\section{Conflict of interest: The authors have no conflict of interest.}

Acknowledgments: Authors wish to acknowledge SERB, Department of Science and Technology, Government of India for the financial support and Dr. Krishna Venkatesh (Director, CIIRC- Bengaluru) for his kind help and support during the entire study.

\section{REFERENCES}

Albdaiwi RN, Khyami-Horani H, Ayad JY, Alananbeh KM, Al-Sayaydeh R (2019) Isolation and characterization of halotolerant plant growth promoting rhizobacteria from durum wheat (Triticum turgidum subsp. durum) cultivated in saline areas of the dead sea region. Front. Microbiol. 10:1639. https://doi.org/10.3389/fmicb.2019.01639

Amaresan N, Jayakumar V, Thajuddin N (2012) Endophytic bacteria from tomato and chilli, their diversity and antagonistic potential against Ralstonia solanacearum. Arch. Phytopathol. Plant Protect 45:344-55 https://doi.org/10.1080/03235408.2011.587273

Baig KS, Arshad M, Shaharoona B, Khalid A, Ahmed I (2012) Comparative effectiveness of Bacillus spp. possessing either dual or single growth-promoting traits for improving phosphorus uptake, growth and yield of wheat (Triticum aestivum L.). Ann. Microbiol. 62:1109-19. https://doi.org/10.1007/s13213-0110352-0

Baker AW, Schippers B (1987) Microbial cyanide production in the rhizosphere in relation to potato yield reduction and Pseudomonas sp-mediated plant growthstimulation. Soil Biol. Biochem. 19:451-7. https://doi.org/10.1016/0038 0717(87)90037-X

Barea JM, Pozo MJ, Azco R, Azcon-Aguilar C (2005) Microbial co-operation in the rhizosphere. J Exp. Bot. 56:1761-78. https://doi.org/10.1093/jxb/eri197 Budi SW, Van TD, Arnould C, Dumas-Gaudot E, Gianinazzi-Pearson V, Gianinazzi S (2000) Hydrolytic enzyme activity of Paenibacillus sp. strain b2 and effects of the antagonistic bacterium on cell integrity of two soil-borne pathogenic fungi. Appl. Soil Ecol. 15:191-99. https://doi.org/10.1016/s0929-1393(00)00095$\underline{0}$

Çakmakç R, Dönmez F, Aydın A, Sahin F (2006) Growth promotion of plants by plant growth promoting rhizobacteria under greenhouse and two different field soil $\begin{array}{lllll}\text { conditions. Soil Biol. } & \text { Biochem. } & \text { 38: }\end{array}$ https://doi.org/10.1016/j.soilbio.2005.09.019

Cappuccino JG, Sherman N (1992) Biochemical activities of microorganisms in Microbiology, a laboratory manual. $1^{\text {st }}$ ed. San Francisco:Pearson/Benjamin Cummings PP. 105-300. https://doi.org/10.2307/1309615

Cruz AF, Ishii T, Matsumoto I, Kadoya K (2002) Network establishment of vesicular-arbuscular mycorrhizal hyphae in the rhizospheres between trifoliate orange and some plants. Jpn Soc. Hortic. Sci. 71:19-25. https://doi.org/10.2503/jjshs.71.19

Fiske CH, Subbarow Y (1925) The colorimetric determination of phosphorus. $J$ Biol. Chem. 66:375-400. https://doi.org/10.1016/s0021-9258(18)84756-1 
Harley JP, Prescott LM (2002) Bacterial morphology and staining: Laboratory exercises in microbiology, 5th edition, The McGraw-Hill Companies, New York, PP. 31-36.

Hassan N, Md. Hasan K, Md. Shaddam O, Islam MS, Barutçular C, Sabagh AEL (2018) Responses of Maize Varieties to Salt Stress in Relation to Germination and Seedling Growth. International Letters of Natural Sciences. Vol. 69, pp 1-11. https://doi.org/10.18052/www.scipress.com/ilns.69.1

Hayat R, Ali S, Amara U, Khalid R, Ahmed I (2010) Soil beneficial bacteria and their role in plant growth promotion: a review. Ann. Microbiol. 60:579-598. https://doi.org/10.1007/s13213-010-0117-1

Hurek T, Reinhold-Hurek B (2003) Azoarcus sp. strain BH72 as a model for nitrogen-fixing grass endophytes. J Biotechnol. 106:69-78 https://doi.org/10.1016/j.jbiotec.2003.07.010

Jadhav HP, Sayyed RZ (2016) Hydrolytic enzymes of rhizospheric microbes in cropprotection. MOJ Cell Sci. Rep. 3:135-36 https://doi.org/10.15406/mojcsr.2016.03.00070

Kandel SL, Firrincieli A, Joubert PM, Okubara PA, Leston ND et al., (2017) An In vitro study of bio-control and plant growth promotion potential of salicaceae endophytes. Front. Microbiol. 8:386. https://doi.org/10.3389/fmicb.2017.00386

Khatoon, T., Hussain, K., Majeed, A., Nawaz, K., Nisar, M.F., 2010 Morphological variations in maize (Zea mays L.) under different levels of $\mathrm{NaCl}$ at germinating stage. World Appl. Sci. J. 8, 1294-7.

Kiely PD, Haynes JM, Higgins CH, Franks A, Mark GL, Morrissey J et al., (2006) Exploiting new systems-based strategies to elucidate plant-bacterial interactions in the rhizosphere. Microb. Ecol. 51: 257-66. https://doi.org/10.1007/s00248-0069019-y

Kim KJ, Yang YJ, Kim JG (2003) Purification and characterization of Chitinase from Streptomyces sp. M-20. J Biochem Mol Biol. 36(2):185-189. https://doi.org/10.5483/bmbrep.2003.36.2.185

Kobayashi DY, Reedy RM, Bick J, Oudemans PV (2002) Characterization of chitinase gene from Stenotrophomonas maltophilia strain $34 \mathrm{~S} 1$ and its involvement in biological control. Appl. Environ. Microbiol. 68:1047-54. https://doi.org/10.1128/aem.68.3.1047-1054.2002

Liu B, Liu G-H, Sengonca C, Schumann P, Wang J-P, Zhu Y-J, Zhang H-F (2017) Bacillus wudalianchiensis sp. nov., isolated from grass soils of the Wudalianchi scenic area. Int. J Syst. Evol. Microbiol. 67:2897-2902. https://doi.org/10.1099/ijsem.0.002042

Mandic-Mulec Ines, Prosser, James (2011) Diversity of Endospore-forming Bacteria in Soil: Characterization and Driving Mechanisms https://doi.org/10.1007/978-3-642-19577-8_2

Nagendran K (2011) Exploitation of endophytes for the management of major diseases of rice. M.Sc. (Ag.) Thesis, Tamil Nadu Agricultural University, Coimbatore, India. pp.200.

Nautiyal CS (1999) An efficient microbiological growth medium for screening phosphate solubilizing microorganisms. FEMS Microbiol. Lett. 170:265-270. https://doi.org/10.1111/j.1574-6968.1999.tb13383.x

Omar A. Almaghrabi, Abdelmoneim T. S., Hassan M. Albishri and Tarek A. A. Moussa(2014) Enhancement of MaizeGrowth Using Some Plant Growth Promoting Rhizobacteria (PGPR) Under Laboratory Conditions. Life Sci J. 11:764-772. (ISSN: 1097-8135).

Panhwar QA, Othman R, Zaharah AR, Meon S, Ismail MR (2011) Effect of phosphatic fertilizer on root colonization of aerobic rice by phosphate-solubilizing bacteria. International Conference on Food Engineering and Biotechnology. IACSIT Press, Singapoore. https://doi.org/10.1007/978-3-319-08216-5_9

Rajendran L, Karthikeyan G, Raguchander T, Samiyappan R (2007) In vitro evaluation of Bacterial endophytes influence on Ganoderma lucidum (Leys) Karst. Mycelial growth. Journal of Plant Protection Research. 47(4):425-436.

Ramette A, Moënne-Loccoz Y, Défago G (2006) Genetic diversity and biocontro potential of fluorescent pseudomonads producing phloroglucinols and hydrogen cyanide from Swiss soils naturally suppressive or conducive to Thielaviopsis basicola-mediated black root rot of tobacco. FEMS Microbiol Ecol. 55:369-381. https://doi.org/10.1111/j.1574-6941.2005.00052.x

Saxena AK, Kumar M, Chakdar H, Anuroopa N, Bagyaraj DJ (2019) Bacillus species in soil as a natural resource for plant health and nutrition. Journal of Applied Microbiology. 128:1583-1594. https://doi.org/10.1111/jam.14506

Schwyn B, Neilands JB (1987) Universal chemical assay for the detection and determination of siderophores. Anal. Biochem. 160:47-56. https://doi.org/10.1016/0003-2697(87)90612-9

Selvi KB, John Paul JA, Ravindran AD, Vijaya V (2011) Quantitative estimation of insoluble inorganic phosphate solubilization. Int. J Sci. Nat. 2:292-95.

Solanki MK, Singh RK, Srivastava S, Kumar S, Srivastava, AK, Kashyup P et al. (2013). Isolation and characterizations of siderophore producing rhizobacteria against Rhizoctonia solani. J Basic Microbiol. 54:585-597. https://doi.org/10.1002/jobm.201200564

Swetha S, Padmavathi T (2016a) Comparative study of solubilization of different inorganic phosphates by Piriformospora indica. Pol. J. Microbiol. 65:407-12 https://doi.org/10.5604/17331331.1227666

Swetha S, Padmavathi T (2016b) Biosynthesis characterization and optimization auxins by piriformospora indica:It's impact on growth of Solanum melongena L. cultivars. J Sci. Ind. Res.75:45-50.
Swetha S, Padmavathi T (2019) Mitigation of drought stress by Piriformospora indica in Solanum melongena L. cultivars. Proc. Natl. Acad. Sci., India, Sect. B Biol. Sci. https://doi.org/10.1007/s40011-019-01128-3

Venkata E, Naga R, Divakar G (2013) Production of pectinase by using Bacillus circulans isolated from dump yards of vegetable wastes. Int J Pharm Sci. Res. 4:2615-22.

Weisburg WG, Barns SM (1991) 16S ribosomal DNA amplification for phylogenetic study. Pelletier DA, Lane DJ. J Bacteriol. 173:697-703. https://doi.org/10.1128/jb.173.2.697-703.1991 